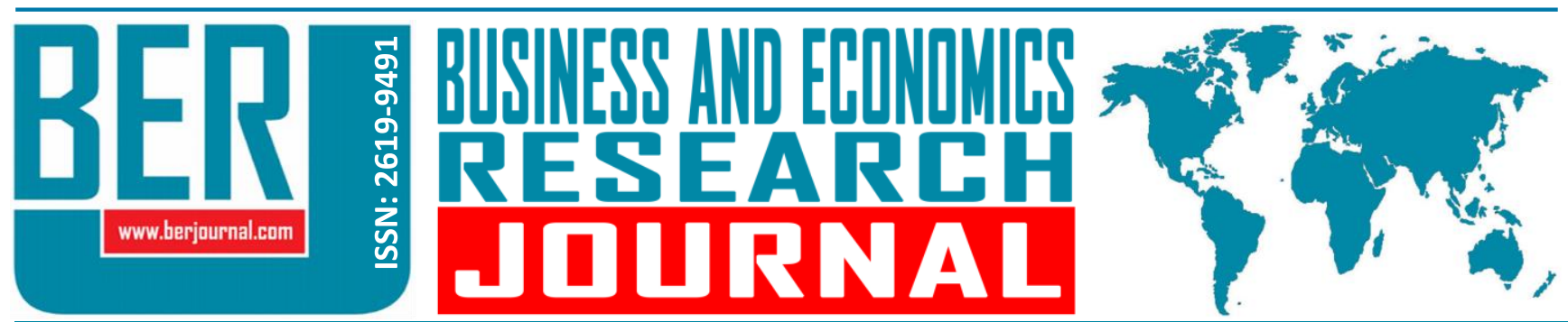

Business and Economics Research Journal Vol. 9, No. 3, 2018, pp. 605-618 doi: 10.20409/berj.2018.126

\title{
2008 Finansal Krizinin BİST 100 Endeksindeki Firmalarının Temettü Dağıtım Politikalarına Etkisi*
}

\author{
Hazal Tasci ${ }^{\mathrm{a}}$, Turhan Korkmaz
}

Öz: Bu çalışmada, hem temettü politikasını etkileyen faktörlerin neler olduğu hem de 2008 Krizi temelinde finansal krizlerin firmaların temettü politikasına etkisi araştırılmıştır. Bu amaç doğrultusunda analiz dönemi, tüm dönem; 2004-2016, kriz öncesi; 2004-2008 ve kriz sonrası; 2009-2016 olarak üçe ayrılmış ve BisT 100 Endeksi'nde listelenen firmalardan oluşan bir örneklemin veri seti kullanılarak panel veri analizi gerçekleştirilmiştir. Sonuçta, bağımlı değişken olan temettü ödeme oranı ile firma kârlıığı, büyüme fırsatları, birikmiş kâr/özkaynak oranı ve nakit oranı arasında pozitif bir ilişki olduğu görülmüştür. Büyüme fırsatları ve temettü ödeme oranı arasındaki ilişki, beklenenin aksine pozitif çıkmıştır. Öte yandan, kriz dönemlerinde firmaların temettü politikasını etkileyen faktörlerin değiştiği ve nakit oranının öneminin arttığı tespit edilmiştir. Yaşanan likidite sıkıntısına bağlı olarak birçok firma 2009-2010 yıllarında temettü ödeme oranlarını düşürmüş fakat ödeme yapmaya devam etmiştir. Bu durum temettünün bilgi içeriği ve sinyal etkisinin kriz dönemlerinde dahi geçerli olduğunu kanıtlamaktadır.

\section{Effects of 2008 Financial Crisis on Dividend Payout Policies of Istanbul 100 Index Listed Companies}

Abstract: In this study, both the factors affecting the dividend policy and the effect of the financial crises on the dividend policy of the companies were examined based on the 2008 Crisis. For this purpose, the analysis period is divided into three parts as whole period; 20042016, pre-crisis period; 2004-2008 and post-crisis period; 2009-2016 and the analysis has been performed by exercising panel data method as using financial data of 43 firms listed in ISE 100 Index. Consequently, a positive relation has been detected among dividend payout ratio being a dependent variable, firm profitability, growth opportunities, retain earning/equity ratio and cash ratio. Contrary to expectations, a positive relationship was found between growth opportunities and dividend payout ratio. On the other hand, it is identified that the factors influencing dividend policy of the firms change and cash ratio increase substantially at crisis periods. Due to the current liquidity problem, many companies have reduced dividend payout ratios in 2009-2010, but continue to pay. This proves that the information content and signaling effect of the dividend is valid even in times of crisis.

\section{Anahtar Sözcükler: Temettü Politikası, Finansal Kriz, BIST 100 , Panel Veri, Sinyal Teorisi \\ JEL: G35, G10

$\begin{array}{ll}\text { Geliş } & : \text { 24 Nisan } 2018 \\ \text { Düzeltme } & : \text { 03 Temmuz } 2018 \\ \text { Kabul } & : \text { 09 Temmuz 2018 } \\ \text { Tür } & : \text { Araştırma }\end{array}$

Keywords: Dividend Policy, Financial Crisis, BIST 100, Panel Data, Signaling Theory

JEL: G35, G10

$\begin{array}{ll}\text { Received } & : 24 \text { April } 2018 \\ \text { Revised } & : 03 \text { July } 2018 \\ \text { Accepted } & : 09 \text { July } 2018 \\ \text { Type } & \text { : Research }\end{array}$

a PhD. Student, Akdeniz University, Institute of Social Sciences, Department of Business Administration, Antalya, Turkiye, hazaltasci@hotmail.com (ORCID ID: 0000-0001-7474-916X)

b Prof., PhD., Mersin University, Faculty of Economics and Administrative Sciences, Department of Business Administration, Mersin, Turkiye, korktur@gmail.com (ORCID ID: 0000-0001-5468-2279)

* Bu çalışma, Prof. Dr. Turhan Korkmaz danışmanlığında Mersin Üniversitesi Sosyal Bilimler Enstitüsü İşletme Anabilim Dalında 2017 yılında yürütülen Hazal Taşçı́nın “Finansal Krizlerin Firmaların Temettü Politikasına Etkisi: 2008 Krizi Temelinde BisT 100 Endeksi'nde Listelenen Firmalar Üzerine Bir Uygulama” başlıklı yüksek lisans tezinden türetilmiştir. 


\section{Giriş}

Firmaların öncelikli amacı kâr elde etmek dolayısıyla ortakların servetlerini maksimize etmek ve firma değerini artırmaktır. Bu amaç doğrultusunda dönem içinde gerçekleşen firma faaliyetleri sonucunda elde edilen kâr, firmanın finansman ve yatırım politikasının bir parçası olarak farklı şekillerde değerlendirilebilir. Dönem sonunda elde edilen kâr, ortaklara temettü olarak dağıtılabileceği gibi yeni yatırımların finansmanında, firma faaliyetlerinin yürütülmesi ve varsa mevcut borçların ödenmesi gibi amaçlar doğrultusunda kullanılabilir. Bu karar firmanın finansal yapısı, ortakların beklentileri ve yatırım fırsatları gibi çok tarafıı bir mekanizmanın ortak çıkarları doğrultusunda alındığı için oldukça önemlidir.

Firmalar açısından bu denli önemli bir konunun finansal istikrarsızlığın ve belirsizliğin yoğunlaştığı kriz dönemlerinde önemi her zamankinden fazladır. Firmanın temettü dağıtım politikasını etkileyen kârıılık, yatırım fırsatları, nakit durumu, borç durumu gibi faktörler genel ekonomik konjonktürden etkilenebilen hassas bir yapıya sahiptir. Bu ilişkinin kuvveti özellikle finansal kriz, volatilite ve buna bağlı olarak belirsizliğin arttığı dönemlerde daha da güçlenmektedir. Bu açıdan finansal krizler ve buna bağı̆ yaşanan likidite sıkıntısı, yatırım fırsatlarının azalması gibi faktörler, firmaların temettü ödemelerini azaltmasına ya da kesmesine neden olabilir. Buna karşın yatırımcıların temettü ya da sermaye kazancı beklentisi, içinde bulunulan risk durumuna göre farklılık gösterebilir. Kriz dönemlerinde, artan risk ve piyasalardaki düşüş, sermaye kazancı elde etmeyi zorlaştıracağı için yatırımcılar kısmen daha güvenli olarak algıladıkları temettü kazancını tercih edebilir.

Bu nedenle bu çalışmanın öncelikli amacı firmaların temettü politikasını etkileyen faktörlerin belirlenmesi ve finansal krizlerin firmaların temettü politikasına ne şekilde etki ettiğinin araştırılmasıdır. Çalışmada kriz dönemi olarak, ABD'de 2007 yılının ortalarında ipotekli konut piyasalarında başlamış ve kısa sürede hem ABD'yi hem de bütün dünyayı etkisi altına almış ve literatürde 2008 küresel krizi olarak adlandırılan kriz ele alınmıştır. Çalışmada bu krizin kullanılmasının nedeni; hem yaşanan en güncel ekonomik kriz olması hem de bütün dünyayı kısa sürede ve derinden sarsan küresel nitelikte bir kriz olmasıdır.

Finans yazınında çok fazla çalışma yapıımış ancak hala üzerinde net bir karar verilememiş önemli bir konunun, finansal istikrarsızlığın ve belirsizliğin yoğunlaştığı kriz dönemlerinde ne şekilde değerlendirileceği, firmaların ve yatırımcıların kararlarının ne olacağı ve bundan sonra yaşanacak herhangi bir küresel krizde temettü politikasının taraflarının ne şekilde önlemler alacağı soruları, bu çalışmanın motivasyonunu artırıcı bir etkiye sahiptir.

Literatürde temettü politikasının belirleyicilerine dair yapılan çalışmalardan Lintner (1956), Fama ve French (2001)'den elde edilen bulguların, Bhattacharya (1979), Rozeff (1982), Easterbrook (1984) ve Jensen (1986)'nın sinyal ve temsil teorilerinin, De Angelo vd. (2006), yaşam döngüsü teorisinin, Türkiye gibi gelişmekte olan bir piyasada özellikle finansal kriz döneminde geçerliliğinin incelenmesi amaçlanmıştır. Temettü politikasına dair Türkiye'deki finansal piyasalar üzerine yapılan çalışmalar genellikle tek bir araştırma sorusu üzerine odaklanmıştır. Adaoğlu (2000) çalışmasında Lintner (1956) modelinden hareketle, temettü düzenlemeleri ve yasal düzenlemelerin temettü düzenlemeleri üzerine etkisini araştırmıştır. Aygören, Çakır ve Uyar (2013), iMKB'de işlem gören firmaların kriz döneminde temettü politikasını incelemişlerdir. Çelik (2013), yaşam döngüsü teorisinin geçerliliğini iMKB üzerinde test etmiş olsa da diğer güncel yaklaşımların geçerliliklerini incelememiştir. Bu bağlamda bu çalışma temettü politikasının belirleyicileri, teorik yaklaşımların geçerlilikleri ve finansal kriz ilişkisini bir arada ele alan ve birden fazla araştırma sorusuna cevap arayan kompakt bir yapı üzerine kurulmuştur.

Çalışmada hem krizin etkisini görmek hem de temettü politikasına ilişkin teorik yaklaşımların geçerliliklerinin test etmek amacıyla 2004-2016 yılları arasında BiST 100 Endeksi'nde işlem gören (mali sektör ve holdingler dışında kalan) 43 firmanın yıllık verilerinden faydalanılmıştır. Finansal tablolarının farklılık göstermesi ve farklı yasal düzenlemelere tabî olmaları nedeniyle mali sektör kuruluşları ve holdingler çalışma kapsamı dışında bırakıımıştır. Geriye kalan en az 5 yıl temettü ödemesi yapan (Kirkulak ve Kurt, 2010: 41) ve verisine ulaşılabilen 43 adet firma olmuştur. Ayrıca analiz dönemi, tüm dönem; 2004-2016, kriz öncesi dönem; 2004-2008 ve kriz sonrası dönem; 2009-2016 olarak üçe ayrılarak panel veri analizi gerçekleştirilmiştir. Analizin sonucunda finansal krizin piyasada yarattığı likidite sıkıntısına bağlı olarak 
firmaların temettü ödemelerini azalttığı, yaşam döngüsü teorisinin geçerli olduğu, Fama ve French (2001)'in kârlılık ve büyüme fırsatları faktörlerinin temettü ödeme oranı ile pozitif ilişkili olduğu bulguları elde edilmiştir.

Çalışmanın birinci bölümü olan giriş bölümünden sonra ikinci bölümde temettü politikasını etkileyen faktörlerden ve konuya ilişkin teorik yaklaşımlardan söz edilmiş, üçüncü bölümünde konuya ilişkin yapılan çalışmalardan oluşan literatüre yer verilmiştir. Çalışmanın dördüncü bölümünü oluşturan uygulama bölümünde panel veri metodolojisi özetlenmiş ve analiz bulguları yorumlanarak tartışılmıştır. Son bölüm olan beşinci bölümde ise sonuç ve önerilere yer verilmiştir.

\section{Temettü Politikasına iliş̧kin Teorik Çerçeve}

Bu bölümde temettü politikasını etkileyen faktörlerin neler olduğu anlatılmış ve firmaların temettü kararlarını açıklamaya çalışan temel ve güncel teorik yaklaşımlara yer verilmiştir.

\subsection{Temettü Politikasını Etkileyen Faktörler}

Firmaların temettü politikalarını etkileyen içsel ve dışsal birçok faktör vardır. Bu bölümde, bu faktörlerin neler olduğu açıklanmıştır.

\subsubsection{Kârlılık}

Temettü ödemeleri, faaliyet dönemi sonunda elde edilen kârların yasal karşılıklar ayrıldıktan sonra ortaklara dağıtılması şeklinde gerçekleştiği için yüksek kârlılık oranlarına sahip firmaların daha fazla temettü ödemesi gerçekleştirmesi beklenir. Özellikle kriz dönemlerinde firmaların satışları ve buna bağlı olarak kârlıık oranları düşer. Dolayısıyla firmalar, ellerinde bulunan nakdi temettü olarak dağıtmak yerine firma bünyesinde tutarak, gelecek dönemlerde derinleşebilme intimali olan likidite krizini yönetebilmek için kullanırlar.

\subsubsection{Yatırım Fırsatları}

Yüksek büyüme potansiyeline sahip ve Net Bugünkü Değeri (NBD) yüksek olan projelere sahip firmalar daha az temettü dağıtma eğilimindedir (Gürsoy, 2007: 629). Ellerindeki nakdi yeni yatırımların finansmanında kullanılmak üzere pazar araştırması, teknolojik gelişmelerin takibi ve ar-ge çalışmaları gibi alanlarda kullanırlar. Ekonomik durgunluk ve kriz dönemlerinde, firmaların yatıım fırsatları oldukça az ve risklidir. Bu durumda elde edilen veya firma bünyesinde bulunan birikmiş kârların kullanılabilecekleri alanlar sınırlanmış olacaktır ve bu fonlara sahip firmalar, ortaklara temettü dağıtarak, krizi yönetebilen güçlü bir firma oldukları yönünde sinyal verebilirler.

\subsubsection{Likidite Durumu}

Bir firmanın likiditesi, firmada bulunan nakit ve nakit benzerleri veya kısa sürede nakde dönüştürülebilen varlıklarıyla ölçülür. İşletme faaliyetlerinden elde edilen kârlar firmaya nakit girişi sağlayacağı için likidite oranını artıracak ve daha fazla temettü dağıtma eğilimine sahip olmasını sağlayacaktır (Demirel, 2014: 23). Likidite durumunu etkileyen önemli etkenlerden birisi de finansal istikrarsızlık ve belirsizlik durumlarının arttığı kriz koşullarıdır. Piyasaların yüksek oranda dalgalanma gösterdiği kriz dönemlerinde firmalar gelecekteki kazançlarından emin olamadıkları ve çok olumlu bir tablo göremedikleri için ellerinde bulunan nakdi temettü olarak dağıtmayacak ve gelecekte yaşanacak nakit sıkıntısını yönetebilmek için kullanacaktır.

\subsubsection{Borçluluk Durumu ve Borçlanabilme Yeteneği}

Firmalar eğer borçla finansman sağlamışlarsa öncelikli olarak vadesi gelen borçlarının faiz ve anaparalarını ödemek durumundadır. Bu durum büyük olasılıkla ellerinde bulunan nakdi borçlarını ödemek için kullanacakları anlamına gelir. Bir firma için likidite durumu tek başına belirsizlik karşısında firmayı korumak için yeterli değildir. Aynı zamanda firmanın borçlanabilme yeteneği de önemlidir çünkü firmaya finansal esneklik sağlar. Bankadan kredi alınabilmesi veya alınan kredinin uzatılması gibi konular 
borçlanabilme yeteneği kapsamında değerlendirilebilir. Buna ek olarak finansal esneklik kapsamında firmaların sermaye piyasasında tahvil ihraç etmesi konusu da vardır. Büyük ve kurumsal şirketler sermaye piyasalarında tahvil gibi borçlanma senetleri yoluyla da borçlanabilirler. Firmanın borçlanma yeteneği ne kadar fazlaysa o kadar esnektir ve o kadar nakit temettü dağıtabilme yeteneğine sahiptir (Van Horne ve Wachowicz, 2008: 482-483).

\subsubsection{Yasal Sınırlamalar}

Firmaların temettü politikalarını oluştururken karşılaştığı en önemli sınırlamalardan biri kanun koyucuların koyduğu sınırlamalardır. Türkiye'de temettü politikalarının belirlenmesine ilişkin yasal düzenlemeler, payları borsada işlem gören şirketler için Sermaye Piyasası Kurulu (SPK), diğer şirketler için ise Türk Ticaret Kanunu (TTK) tarafından belirlenir. Sermaye Piyasası Kurulu'nun (SPK), 23.01.2014 tarihli ve 28891 sayılı tebliği uyarınca, "Payları borsada işlem görmeyen halka açık ortaklıkların, bağışlar eklenmiş net dağıtılabilir dönem kârının yüzde yirmisinden az olamayacak şekilde kâr payını tam ve nakden dağıtmalarının zorunlu olduğu düzenlenmiştir" (SPK, 2016).

\subsubsection{Vergi}

Gelir vergisi kanuna göre temettü gelirleri sermaye iradı kapsamında değerlendirilir ve vergiye tabidir (GiB, 2016). Firmaların elde ettikleri kâr arttıkça doğru orantılı olarak ödeyecekleri gelir vergisi de artacaktır. Bu anlamda bazı yatırımcılar, büyük ve yüksek kârlı firmalara yatırım yapmaktansa, büyüme potansiyeli gösteren ve elde ettiği kârları dağıtmayıp NBD'si yüksek projelere yönlendirerek firma değerini artırabilecek firmalara yatırım yapmayı tercih ederler. Zira payların değer artışından elde edilen sermaye kazancı, temettü gibi kaynaktan stopaj vergisine tabî değildir ve bazı istisnaları mevcuttur.

\subsection{Temettü Politikasına İlişkin Teorik Yaklaşımlar}

Bu bölümde öncelikle temettü politikasının firma değeri ile ilişkisini inceleyen temel teorilere, daha sonra güncel teorik yaklaşımlara yer verilmiştir.

\subsubsection{MM ilintisizlik Teorisi}

Franco Modigliani ve Merton Miller tarafından ileri sürülen temettü ilişkisizliği modeline göre temettü politikası, bir firmanın pay fiyatı ve sermaye maliyeti üzerinde herhangi bir etkiye sahip olmamakta, firmanın değeri (dolayısıyla payların değeri) yalnızca temel kazanma gücü ve işletme riski tarafından belirlenmektedir. Modigliani ve Miller'a göre yatırımcı yatırımdan sağlanacak gelirin temettü veya sermaye kazancı olması konusunda kayıtsızdır (Aksöyek ve Yalçıner, 2011: 304). Fakat MM görüşü mükemmel piyasa şartlarında geçerli olduğu için günümüz piyasa şartlarının mükemmel olmayışı, teorinin geçerliliğini sınırlandırmaktadır.

\subsubsection{Eldeki Kuş Teorisi}

John Lintner'in 1962 yılında yayınlanan "Kâr Payı, Kazanç Kaldıracı, Pay Fiyatları ve İşletmelere Sermaye Sağlama" ve Myron Gordon'in 1963 yılında yayınlanan "Optimum Yatıım ve Finansman Politikası" isimli makalelerinde $\mathrm{MM}^{\prime}$ 'in görüşünün tam aksine kâr payı politikalarının şirket değeri üzerinde bir etkisi olduğunu savunmuşlardır. Gordon ve Lintler kâr payı ödemelerindeki azalmaya bağlı olarak sermaye maliyetinin artacağını savunmuşlardır. Bu görüşe göre yatırımcılar kâr payı gelirinin sermaye kazancından daha az riskli bulmalarından dolayı kâr payı getirisini eldeki kuş, sermaye kazancını da daldaki kuşa benzetmektedir. Bu teoriye göre işletme kâr payı dağıtmayıp oto finansman yaparsa kazancın elde edilmesi için geçen süre uzayacak ve pay sahiplerinin beklenen getirileri (özsermaye maliyeti) artacaktır. Hissedarların beklenen getirilerinin artması, payların fiyatlarının düşmesi şeklinde yorumlanmaktadır. Böylece yüksek oranda kâr payı dağıtımı öz sermaye maliyetini düşüreceğinden tavsiye edilmektedir (Pekkaya, 2006: 192). 


\subsubsection{Sinyal Teorisi}

Sinyal teorisi, temettü dağıtımındaki değişikliklerin, yatırımcılara ve piyasaya firmanın gelecek dönem kazançları hakkında bilgi taşıma özelliğine sahip olduğunu ileri süren bir teoridir. Asimetrik bilginin hâkim olduğu gerçek piyasa koşullarında, yatırımcılar ve yöneticiler firma hakkında eşit şekilde bilgiye sahip değildir. Dolayısıyla sinyal teorisi, yönetimin, firmanın geleceğini nasıl gördüğü hakkında yatırımcılara ipuçları sağlar. Bhattacharya (1979), temettülerin firmanın gelecekteki performansının "içeriden öğrenenlerin" (yöneticiler) beklentisine işaret ettiğini savunmuştur. Easterbrook (1984) temettü ödemelerinin iyi ya da kötü sinyal verip vermediklerini tespit etmenin zor olduğunu ve sadece temettü ödemesine bakarak bir firmanın gelecek performansının iyi olacağına karar vermenin yanlış olduğunu savunmuştur. Sinyal teorisine ilişkin yapılan çalışmalar genelde istikrar dönemlerine ilişkin olup ekonominin kötüye gittiği finansal kriz dönemlerinde temettünün sinyal etkisinin önermelerinin geçerlilikleri pek fazla test edilmemiştir. Bozos, Nikolopoulos ve Ramgandhi (2011) çalışmalarında, kriz dönemlerinde sinyal teorisinin Londra Borsası'nda geçerliliğini araştırmış ve ekonomik koşullarla temettünün bilgi içeriği arasında önemli bir etkileşim olduğunu savunmuşlardır. Temettü sinyal verme hipotezini istikrarlı ve durgun ekonomik koşullar altında test ettikten sonra temettülerin büyüme ve istikrar dönemlerinde kazançlardan daha az bilgi verme içeriğine sahip olduğunu ancak ekonomik sıkıntılı dönemlerde daha fazla bilgi içerdiğini tespit etmişlerdir.

\subsubsection{Temsil Maliyeti Teorisi}

Modern şirketlerde sahiplikten doğan hakların sınırlı sorumluluk koşuluna bağlı olarak alanında uzman olan yöneticilere devredilmesi durumu literatürde asıl-vekil ilişkisi ya da temsil ilişkisi olarak adlandırılır. Özellikle büyük ve halka açık firmalarda, firma sahipleri (ortaklar), kendi servetlerini maksimum kılacak yönetim bilgi ve beceresine sahip olmayabilirler. Ya da bunun için ayıracak zamanları olmayabilir. Bu durumda firma kontrolünü, bir yönetim hiyerarşisi kurarak, alanında uzman yöneticilere, onların haklarını temsil etmesi için devrederler. Bu bakımdan şirket temsil edilenler ile temsilciler arasındaki sözleşmeler sistemi olarak nitelenmektedir (Kargın, 2006: 13). Yöneticiler, kendi çıkarlarını korumak ve mevcut pozisyonlarını koruyarak bireysel risklerini azaltmak için firmanın çıkarlarıyla ters düşen kararlar alabilir. Firmalar ne kadar çok nakit akışına sahipse yöneticilerin kaynakları o derece israf etmesi söz konusu olacağından etkin kaynak kullanımı ve temsil maliyetinin önlenmesi açısından temettü dağıtılması bir çözüm olarak önerilir. Easterbrook (1984) ve Rozeff (1982) çalışmalarında temsil maliyetini azaltmak için temettü ödemesi gerçekleştirilebileceğini açıklamışlardır. Jensen (1986), temettü ödemelerinin temsil maliyetini azaltabileceğini savunmakla birlikte temsil maliyetinin serbest nakit akışlarından kaynaklandığını, serbest nakit akışııın ise firmanın net bugünkü değeri pozitif olan bütün projelere gerekli fon ayrıldıktan sonra kalan nakit olduğunu iddia etmektedir. Dolayısıyla serbest nakit akışı fazla olan firmalarda çıkar çatışması artacaktır. Bunu engellemek için yöneticiler temettü açıklamaları yaparak gelecekte elde edecekleri nakit akışlarını sürekli olarak dağıtacakları sözünü verebilirler.

\subsubsection{Asimetrik Bilgi Teorisi}

Asimetrik bilgi, firma içinde yöneticilerin sahip olduğu bilgiyle ortakların veya diğer yatırımcıların sahip olduğu bilginin aynı olmaması durumudur. Yöneticiler firmanın geleceği konusunda daha derin ve teknik bilgilere sahip oldukları için onların beklentileri ile yatırımcıların beklentileri çelişir. Yeni ihraç edilen bir paya, firmanın biçtiği değerle yatırımcının biçtiği değer aynı değildir. Yatırımcı daha düşük bir fiyattan satın almak isteyecek ve firma ihtiyacı olan fonu sağlayacak pay başına fiyattan satış yapacak bir yatırımcı profilini karşısında bulamayacaktır. Bu durumda finansal hiyerarşi kuramı gereğince ihtiyaç duyulan fon, önce iç kaynaklardan daha sonra borç ve en son pay ihracı yoluyla sağlanacaktır. İç kaynaklardan sağlanan fon dağıtılmamış kârlardır. Dağıtılmamış kârlar, firmanın ihtiyaç duyduğu finansmanı sağlamak amacıyla kullanıldığı için ortaklara temettü dağıtılamayacak veya çok düşük bir miktarda dağıtılacaktır. 


\section{Literatür}

Literatürde temettü politikası üzerine yapılan çok sayıda çalışma bulunmaktadır. Bu bölümde temettü politikasının belirleyicilerine dair yapılan temel çalışmalarla birlikte temettü ödemeleri ve finansal kriz arasındaki ilişkiyi inceleyen çalışmalara yer verilmiştir.

Lintner (1956), 28 şirketin yöneticisiyle röportaj yapmış ve her yıl bağımsız bir şekilde o yılın kazancına göre temettü ödemesi yapmak yerine temettü dağıtım oranlarının bir önceki yıla göre düzenlendiğini görmüştür. Yöneticiler, ancak başka seçenekleri kalmadığında temettü ödemelerini azalttıklarını ve gelecekteki nakit akışlarının sürdürülebilir olduğuna emin olduklarında temettü tutarını arttırdıklarını iddia etmişlerdir. Yatırımcıların, dalgalanan temettü ödemeleri yerine, sabit ve düzenli ödemesi yapan firmaların payları için daha fazla pirim ödemeye razı oldukları tespit edilmiştir. Ayrıca, piyasanın temettü kesintisi yapan firmaları düşük fiyatlandırarak cezalandırdığı da bulgular arasındadır.

Fama ve French (2001), çalışmalarında 1929-1999 yılları arası arasında NYSE, AMEX ve NASDAQ verilerini kullanarak logit regresyon yöntemiyle, temettü ödeyen firmaların yapılarını incelemiş ve temettü ödeyen firmalar için üç özellik tespit etmişlerdir. Kârlılık, yatırım fırsatları ve firma büyüklüğü. Büyük ve kârlı firmaların temettü ödemeleri daha yüksekken, yatırım fırsatları fazla olan firmaların daha az temettü ödediği tespit edilmiştir. Ayrıca, 1978'den sonra temettü oranlarının keskin bir düşüş gösterdiğini, 1973'te \%52,8 iken, 1978 ' de zirve yaparak temettü ödeme oranın $\% 66,5$ olduğunu, daha sonra bu oranın sürekli olarak düştüğünü ve 1999 'da firmaların sadece \%20,8 oranında temettü ödediğini tespit etmişlerdir.

De Angelo, De Angelo ve Stulz (2006), çalışmalarında temettü kararları ile firmaların sermaye yapısı arasındaki ilişkiyi 1973-2002 yılları arasında NYSE, NASDAQ ve AMEX verilerini kullanarak test etmişlerdir. Birikmiş kâr/toplam özkaynak, toplam özkaynak/toplam varlıklar ve nakit varlıklar/toplam varlıklar gibi oranlar bağımsız değişken olarak kullanmış ve söz konusu değişkenler ile temettü ödeme oranları arasında anlamlı bir ilişki bulmuşlardır. Yaşam döngüsü teorisi olarak açıkladıkları bu modelde; büyük, yüksek kârlı ve olgunluk seviyesindeki firmaların daha fazla temettü ödeme eğiliminde olduklarını yeni kurulan veya büyüme seviyesindeki firmaların, daha küçük ve az kârlı oldukları için daha az temettü ödeme eğiliminde olduklarını savunmuşlardır. Yaşam döngüsü modelinin temel değişkeni birikmiş kârlar/toplam özkaynak'tır.

Al-Kuwari (2009), çalışmasında Körfez İşbirliği Konseyi (GCC) pay piyasasında listelenen firmalardan oluşan bir örneklemin, 1999-2003 yılları itibariyle temettü politikalarını incelemiştir. Çalışmanın amacı, temettü ödemelerini etkileyen faktörlerin belirlenmesidir. Bu bağlamda, bağımlı değişken; temettü ödeme oranı ve bağımsız değişkenler; büyüklük, kârlılık, büyüme oranı, işletme riski, serbest nakit akışı, sahiplik yapısı ve kaldıraç olarak belirlenmiştir. Sonuçta, kamu firmaları, kârlılık ve büyüklüğün temettü oranı ile istatistiksel olarak anlamlı ve pozitif yönlü bir ilişkisi olduğu tespit edilmiştir. Kaldıraç ile temettü oranı arasında ise negatif yönde anlamlı bir ilişki olduğu görülmüştür. Çalışmanın bulgularından hareketle, bu firmalar için temsil maliyeti teorisinin geçerli olduğu sonucuna ulaşılmıştır. Ayrıca; Körfez Ülkeleri İşbirliği Konseyine üye işletmelerin, uzun süreli olarak hedef temettü oranı belirlemedikleri, sık sık temettü oranı üzerinde düzenlemeler yaptıkları görülmüştür.

Abor ve Bokpin (2010), çalışmalarında kurumsal finans ve yatırım fırsatları ile temettü politikası arasındaki ilişkiyi incelemiştir. 34 adet gelişmekte olan ülkeden oluşan örneklemin veri seti kullanılarak 19902006 yılları arasındaki 17 yıllık bir periyod için panel veri analizi gerçekleştirilmiştir. Sonuçta yatırım fırsatları ve temettü politikası arasında negatif ve anlamlı bir ilişki olduğu görülmüştür. Ancak çeşitli kurumsal yönetim ölçütleri olarak adlandırılan finansal kaldıraç, dışarıdan fon sağlama ve borcun olgunluk seviyesi gibi kavramların temettü politikası üzerinde anlamlı bir etkisinin olmadığı tespit edilmiştir. Ayrıca kârlılık ve piyasa kapitalizasyonu temettü ödemelerini etkileyen diğer önemli faktörler olarak görülmüştür.

Abreu ve Gulamhussen (2013), çalışmalarında, ABD'deki 462 bankanın temettü ödemelerini kriz öncesi ve kriz dönemi (2007-2009) olmak üzere incelemişlerdir. Temettü ödemelerini, Fama ve French'in (2001) üç faktörü (büyüklük, kârııık, büyüme fırsatları) ile açıklamaya çalışmış, buna ek olarak temsil maliyeti ve sinyal hipotezlerini de kriz ve kriz öncesi dönem için test etmişlerdir. Temsil maliyetini ölçmek için bağımsızlık değişkenini kullanırken sinyal etkisini ölçmek için beklenen büyüme fırsatları değişkenini 
kullanmışlardır. Sonuçta, temettü ödemelerinin makroekonomik ortama (finansal kriz öncesi ve sırasında) bağlı olduğu tespit edilmiştir. Fama ve French (2001) özellikleri - daha büyük, daha karlı ve düşük büyüme gösteren bankaların her iki dönem (kriz öncesi ve sırasında) için de daha fazla temettü ödeme eğiliminde olduğu görülmüştür. Ayrıca, bulgular, temettülerin finansal kriz döneminde de olsa, gelecekteki büyüme fırsatlarının bir işareti olarak sinyal hipotezini desteklemektedir.

Çelik (2013), çalışmasında payları iMKB İmalat sektöründe işlem gören şirketlere ait 2006-2011 dönemine ait verileri kullanarak ve logit, probit modeller uygulanarak yaşam döngüsü teorisinin Türkiye'de geçerliliği test etmiştir. Sonuçta yaşam döngüsünün geçerliliğine yönelik bulgular elde edilmiştir. Buna ek olarak kârlılığı ve nakit oranı yüksek olan şirketlerin daha fazla temettü ödeme eğiliminde olduğu görülmüştür.

Kouser, Luqman, Yaseen ve Azeem (2015), çalışmalarında yaşam döngüsü değişkenlerini kullanarak finansal krizlerin temettü politikasına olan etkisini test etmeyi amaçlamışlardır. Bunun için logit model kullanılmıştır. Karachi Stock Exchange (KSE)'de finansal olmayan sektörde işlem gören firmalardan Fama ve French yöntemi kullanılarak 285 adet seçilerek örneklem oluşturulmuştur. 2001-2011 yılları arası bu ilişki (kriz-temettü politikası) panel veri kullanılarak incelenmiştir. Sonuçta kriz döneminde temettülerin anlamlı bir şekilde değiştiği görülmüştür. Araştırma, finansal kriz dönemlerinde, şirketlerin yüksek likiditeyi koruma eğiliminde olduğunu bu nedenle temettü ödemelerinin azaldığını ortaya koymuştur.

Mehdi (2017) çalışmasında kurumsal yönetimin temettü politikasına etkisinin kriz dönemlerinde değişiklik gösterip göstermediğini araştırmıştır. Gelişmekte olan ülke piyasalarından 362 adet mali sektör dışında firma seçilmiş ve panel regresyon gerçekleştirilmiştir. Sonuçlar, kurumsal sahiplik ve yönetim kurulu etkinliği ile birlikte temettü dağıtım kararıın arttığının kanıtlarını ortaya koymaktadır. Yazarlar, gelişmekte olan ülkelerde CEO ikiliği (Genel müdürün aynı zamanda yönetim kurulu üyesi olması) olan ve CEO ikiliği olmayan firmaların temettü politikasının aynı faktör setine bağlı olmadığını bulmuşlardır. Sahiplik yoğunluğunun ve yönetim kurulunun bağımsızlı̆ının, CEO ikiliği olan firmaların temettü politikalarını önemli derecede etkilediği gösterilmiştir. Son olarak sonuçların, son finansal kriz sırasında temettü kararının CEO'nun ikiliğine, yönetim kurulu büyüklüğüne ve yönetim kurulu toplantılarının sıklığına ters orantılı olduğu görülmüştür.

\section{2008 Finansal Krizinin BIST 100 Endeksinde Listelenen Firmaların Temettü Ödeme Politikalarına Etkisinin Analizi}

Bu bölümde çalışmada kullanılan veri seti ve yöntem açıklanmıştır. Daha sonra değişkenler, model ve hipotezlere yer verilmiş ve elde edilen bulgular tartışılarak yorumlanmıştır.

\subsection{Veri ve Metodoloji}

2008 finansal krizinin BiST 100 Endeksinde listelenen firmaların temettü ödeme politikalarına etkisini tespit etmek amacıyla 43 adet firmadan oluşan örneklemin, 2004-2016 yılları arasındaki verileri kullanılarak panel veri analizi gerçekleştirilmiştir. Finansal tablolarının farklılık göstermesi nedeniyle holdingler ve mali sektör kuruluşları çalışma kapsamına alınmamıştır. Holdingler ve mali sektör kuruluşları dışında analiz dönemi içerisinde en az 5 kez temettü ödemesi gerçekleştirmiş olan 43 firma çalışmaya dahil edilmiş ve bu firmalara ait veriler Financial Information News Network, FiNNET (www.finnet.com) adlı finansal veri sağlama kuruluşundan elde edilerek analiz gerçekleştirilmiştir. Krizin etkisini görmek amacıyla analiz dönemi kriz öncesi (2004-2008), kriz sonrası (2009-2016) ve tüm dönem (2004-2016) olarak üçe ayrılmıştır.

Çalışmanın analizi panel veri yöntemi kullanılarak gerçekleştirilmiştir. Panel veri ya da dikey veri, tipik olarak bir birime ait verilerin zaman serisi olarak gözlemlenmesiyle oluşur. Dolayısıyla panel veride yatay kesit ve zaman olmak üzere en az iki boyut vardır (Hsiao, 2005: 1). Aslında panel veri yatay kesit gözlemleri olarak adlandırılan, bireyler, ülkeler firmalar, hane halkı gibi N sayıda birim ile T sayıda dönemin bir araya gelmesiyle oluşmaktadır (Tatoğlu, 2016: 2). 
Panel verilerle çalışıldığında, her bir birim tüm zamanlar boyunca gözlenmişse dengeli panel, bazı birimler için bazı zamanlar kayıpsa dengesiz panel söz konusu olur. Genel olarak doğrusal panel veri modeli aşağıdaki gibi ifade edilir (Tatoğlu, 2016: 37):

$$
Y_{\text {it }}=\alpha+\beta_{1 i t} X_{1 i t}+\ldots+\beta_{\text {kit }} X_{\text {kit }}
$$

Panel veri metodolojisinin bazı varsayımları olmakla beraber bu çalışmada hepsi sınanmamıştır. Baltagi (2005), yatay kesit gözlem sayısının (N) ve zaman serisi gözlem sayısının (T) fazla olduğu makro ve orta panellerde serilerin durağan olmaması varsayımı nedeniyle birim kök olup olmadığının sınanması gerektiğini ancak T'nin 20'den küçük olduğu mikro panellerde birim köke bakılmasına gerek olmadığını savunmuştur (Baltagi, 2005: 245). Erlat (2015) ise mikro panellerde çoklu doğrusal bağlantı ve yatay kesit bağımlılığı varsayımlarının sınanmasına gerek olmadığını vurgulamıştır. Bu varsayımlar altında bu çalışmada kullanılan bir mikro panel olduğu için $(T=13)$ birim kök, çoklu doğrusal bağlantı ve yatay kesit bağımlılığı testlerine gerek duyulmamıştır.

Çalışmada panel verinin bu üç varsayımı dışında kalan serilerde otokorelasyon ve değişen varyans sorununun olmaması varsayımlarının geçerlilikleri test edilmiştir. Otokorelasyon sorunun tespiti için Baltagi ve Li (1995) ve Born ve Breitung (2016) tarafından geliştirilen otokorelasyon testleri kullanılmıştır. Her iki testin de hipotezi şu şekildedir:

$\mathrm{H}_{0}$ : Otokorelasyon yoktur.

$\mathrm{H}_{1}$ : Otokorelasyon vardır.

Değişen varyans sorunun tespiti için de Breusch ve Pagan (1979) tarafından geliştirilen LM testi kullanılmıştır. Heteroscedasticity testinin hipotezleri aşağıdaki gibidir:

$H_{0}$ : Değişen varyans yoktur.

$\mathrm{H}_{1}$ : Değişen varyans vardır.

\subsection{Model ve Hipotezler}

Çalışmada yukarıda aktarılan bilgiler ve ana model ışığında, kriz öncesi; 2004-2008, kriz sonrası; 20092016 ve tüm dönem; 2004-2016 olmak üzere her üç model için kurulan denklem aşağıdaki gibidir:

$$
\mathrm{TO}_{i t}=\alpha+\beta_{1} \mathrm{BYK}_{\mathrm{it}}+\beta_{2} \mathrm{AK}_{\mathrm{it}}+\beta_{3} \mathrm{PD}_{\mathrm{it}}+\beta_{4} \mathrm{BKTO}_{i \mathrm{t}}+\beta_{5} \mathrm{TOTA}_{\mathrm{it}}+\beta_{6} \mathrm{NO}_{\mathrm{it}}+\mathrm{u}_{\mathrm{it}}
$$

Bağımlı değişken; temettü ödeme oranı iken, bağımsız değişkenler; firma büyüklüğü (toplam varlıkların logaritması), aktif kârlıı̆ı (net kâr/toplam aktif), piyasa değeri/defter değeri, birikmiş kâr/toplam özkaynak, toplam özkaynak/toplam aktif ve nakit oranıdır. Piyasa değeri/defter değeri büyüme fırsatlarının, nakit oranı likiditenin, birikmiş kâr/toplam özkaynak ise De Angelo vd. (2006)'nin yaşam döngüsü teorisinden hareketle firmanın olgunluk seviyesinin göstergesi olarak kullanılmıştır.

Her üç dönem içinde kurulan modelde sınanan hipotezler şu şekildedir:

$H_{1}$ : Temettü ödeme oranı ile firma büyüklüğü arasında pozitif bir ilişki vardır.

$\mathrm{H}_{2}$ : Temettü ödeme oranı ile firma kârlııı̆ı arasında pozitif bir ilişki vardır.

$\mathrm{H}_{3}$ : Temettü ödeme oranı ile firmanın büyüme fırsatları arasında negatif bir ilişki vardır.

$\mathrm{H}_{4}$ : Temettü ödeme oranı ile firmanın olgunluk seviyesi arasında pozitif bir ilişki vardır.

$\mathrm{H}_{5}$ : Temettü ödeme oranı ile toplam özkaynak/toplam varlık oranı arasında pozitif bir ilişki vardır.

$H_{6}$ : Temettü ödeme oranı ile firmanın likidite oranı arasında pozitif bir ilişki vardır.

$H_{7}$ : Kriz öncesi dönemde temettü oranını etkileyen faktörler arasında değişim vardır. 
$\mathrm{H}_{8}$ : Kriz sonrası dönemde temettü oranını etkileyen faktörler arasında değişim vardır.

\subsection{Bulgular ve Tartışma}

Panel veri analizine geçmeden önce hangi panel veri yönteminin seçileceğine karar verilmesi gerekir. Belirli bir anakütle üzerinden rassal olarak seçilen bir örneklemin analiz edilmesi durumunda rassal etkiler modeli gündeme gelir. Bu çalışmada örneklem rassal olarak seçilmemiştir. Belirli bir endeks içindeki firmalar bilinçli olarak seçilmiştir. Dolayısıyla yapılması gereken havuzlanmış (pooled) panel veri modeli ya da sabit etkiler (fixed effect) modelinin seçimine karar vermektir. Bunun için $\mathrm{F}$ testi kullanılmıştır.

Tablo 1. Model 1 (Tüm Dönem) için F Testi Sonuçları

\begin{tabular}{|ccc|}
\hline Test & İstatistik & p-değeri \\
\hline \hline F-grup_sabit & 4,197428 & 0,000000 \\
F-zaman_sabit & 0,980755 & 0,466089 \\
F-iki yön sabit & 3,433379 & 0,000000 \\
\hline
\end{tabular}

F testinde sınanan hipotezler şunlardır:

- Grup etkisini test etmek için- $\mathrm{H}_{0}$ : Kesit etkisi varken zaman etkisi yoktur.

- Zaman etkisini test etmek için- $\mathrm{H}_{0}$ : Zaman etkisi varken kesit etkisi yoktur.

- Yönünü test etmek için- $\mathrm{H}_{0}$ : Kesit ve Zaman Etkisi yoktur.

Test sonuçları Tablo 1'de gösterilmiştir: Buna göre, $p$ değeri $0,00<0.05$ olduğundan grup etkisini sınayan $\mathrm{H}_{0}$ hipotezi reddedilir. Bu durumda $\mathrm{F}$ testi sonuçlarına göre zaman etkisi varken kesit etkisi olmayan ancak kesit etkisi varken zaman etkisi olan tek yönlü sabit etkiler modeli kullanılacaktır. $F$ testi her üç model içinde uygulanmış ve sonuçlara göre; Model 2 (kriz öncesi) için kesit ve zaman etkisi olan iki yönlü sabit etkiler modeli ve Model 3 (kriz sonrası) için tek yönlü sabit etkiler modeli kullanılması gerektiği tespit edilmiştir.

Tablo 2. Model 1 (Tüm Dönem) için Değişen Varyans ve Otokorelasyon Test Sonuçları

\begin{tabular}{|ccc|}
\hline Test & İstatistik & p-Değeri \\
\hline \hline $\begin{array}{c}\text { Heteroscedasticity Testi } \\
\text { LMh_fixed }\end{array}$ & 1572,003 & 0,000000 \\
& & \\
\hline \hline $\begin{array}{c}\text { Otokorelasyon Testleri } \\
\text { LMp-stat }\end{array}$ & 79,29308 & 0,000000 \\
LMp*-stat & 118,9290 & 0,000000 \\
\hline
\end{tabular}

Tablo 2'de de görüldüğü gibi LM testlerinin p değerleri her iki test için de 0,00 'dır. $0,00<0,05$ olduğu için her iki testinde $\mathrm{H}_{0}$ hipotezi reddedilir. Bu durumda Model 1 (tüm dönem) için hem otokorelasyon hem de değişen varyans sorunu mevcuttur. Aynı testler Model 2 (kriz öncesi) ve Model 3 (kriz sonrası) için gerçekleştirildiğinde her üç modelde de hem otokorelasyon hem de değişen varyans sorunu olduğu tespit edilmiştir. Sorunun çözümü için White katsayı düzeltme metodu kullanılmıştır. Gerekli düzeltmelerden sonra Model 1 (tüm dönem) için elde edilen panel regresyon sonuçları Tablo 3'deki gibidir: 
Tablo 3. Model 1 (Tüm Dönem) için EGLS Sonuçları

\begin{tabular}{|c|c|c|c|c|}
\hline $\begin{array}{l}\text { Bağımlı Değişken: T } \\
\text { Yöntem: Panel EGLS } \\
\text { Dönem: 2004-2016 } \\
\text { Zaman Boyutu Gözl } \\
\text { Yatay Kesit Gözlem } \\
\text { Total panel (dengeli }\end{array}$ & $\begin{array}{l}\text { Cross-sectio } \\
\text { Sayısı T: } 13 \\
\text { yısı N: } 43 \\
\text { jözlem Sayıs }\end{array}$ & weights) & & \\
\hline Değişken & Katsayı & Std. Hata & t-i̇statistiği & Prob. \\
\hline TOTA & 0,009707 & 0,160159 & 0,060610 & 0,9517 \\
\hline PD & 0,078588 & 0,014962 & 5,252394 & 0,0000 \\
\hline NO & 0,057246 & 0,264639 & 0,216317 & 0,8288 \\
\hline BYK & 0,012988 & 0,045724 & 0,284042 & 0,7765 \\
\hline BKTO & 0,270532 & 0,126608 & 2,136776 & 0,0331 \\
\hline AK & 0,009704 & 0,003453 & 2,810073 & 0,0051 \\
\hline C & 0,380846 & 0,963642 & 0,395215 & 0,6928 \\
\hline \multicolumn{5}{|c|}{ Etki Özellikleri } \\
\hline R-squared & 0,490434 & \multicolumn{3}{|c|}{ Mean dependent var1,480489 } \\
\hline Adjusted R-squared & 0,442474 & \multicolumn{3}{|c|}{ S.D. dependent var 1,790050} \\
\hline $\begin{array}{l}\text { S.E. of regression } \\
\text { F-statistic }\end{array}$ & $\begin{array}{l}1,469278 \\
10,22606\end{array}$ & \multicolumn{2}{|c|}{$\begin{array}{l}\text { Sum squared resid } \\
\text { Durbin-Watson stat }\end{array}$} & $\begin{array}{l}1100,977 \\
1,216715\end{array}$ \\
\hline Prob(F-statistic) & 0,000000 & & & \\
\hline
\end{tabular}

Tablo 3'e bakıldığında modelin genel olarak anlamlı olduğu görülmektedir (prob. $0,00<0,05$ ). Bağımsız değişkenler ile bağımlı değişken temettü ödeme oranı (TO) arasındaki ilişki incelendiğinde piyasa değeri/defter değeri (PD), birikmiş kâr/toplam özkaynak (BKTO) ve aktif kârııı̆ı (AK) ile bağımlı değişken TO arasında pozitif yönlü ve istatistiki olarak anlamlı bir ilişki olduğu görülmektedir. PD'deki \%1'lik değişim TO'da aynı yönde $\% 7,86$ oranında bir değişime neden olmaktadır. BKTO'daki \%1'lik değişim TO'da aynı yönde $\% 27,05^{\prime}$ lik bir değişime neden olmaktadır. Son olarak AK'deki \%1'lik değişim TO'da aynı yönde \%0,97'lik bir değişime neden olmaktadır. Bütün analiz dönemini gösteren 2004-2016 periyodunda AK ve PD'nin TO ile anlamlı bir ilişkiye sahip olması Fama ve French (2001)'in bulgularını destekler niteliktedir. Büyüme fırsatlarının göstergesi olarak kullanılan PD ile TO arasında beklenen ilişkinin yönü negatif iken elde edilen sonuçlara göre pozitif olduğu görülmüştür. Bu durumun muhtemel iki nedeni olabilir. Birincisi büyüme fırsatlarının göstergesi olarak PD’nin kullanılması doğru olmayabilir. İkincisi ise gelişmekte olan ülkelerdeki firmaların yapısı ile gelişmiş ülkelerdeki firmaların yapısı farklılık gösterebilir. Bu nedenle Fama ve French (2001)'in çalışması ve onu temel alarak geliş̧̧ş ülke piyasalarına ilişkin yapılan çalışmalar ile gelişmekte olan ülke piyasalarına ilişkin yapılan çalışmalar aynı sonucu vermeyebilir. Yaşam döngüsü teorisinin kilit değişkeni olan ve firmanın olgunluk seviyesini gösteren BKTO ile TO arasındaki ilişki ise beklendiği gibi pozitif yönde ve anlamlı çıkmıştır. Bu sonuç yaşam döngüsü teorisini desteklemekte yani olgunluk seviyesi yüksek olan firmaların daha fazla temettü ödeme eğiliminde olduğunu ortaya koymaktadır. 
Tablo 4. Model 2 (Kriz Öncesi) için PLS Sonuçları

\begin{tabular}{|c|c|c|c|c|}
\hline \multirow{2}{*}{\multicolumn{5}{|c|}{ Bağımlı Değişken: TO }} \\
\hline & & & & \\
\hline \multicolumn{5}{|c|}{ Yöntem: Panel En Küçük Kareler } \\
\hline \multicolumn{5}{|c|}{ Dönem: $2004-2008$} \\
\hline \multicolumn{5}{|c|}{ Zaman Boyutu Gözlem Sayısı T: 5} \\
\hline \multicolumn{5}{|c|}{ Yatay Kesit Gözlem Sayısı N: 43} \\
\hline \multicolumn{5}{|c|}{ Total Panel (dengeli) Gözlem Sayısı: 215} \\
\hline Değişken & Katsayı & Std. Hata & t-İstatistiği & Prob. \\
\hline C & 48,49429 & 35,90088 & 1,350783 & 0,1786 \\
\hline $\mathrm{AK}$ & 0,023147 & 0,028103 & 0,823634 & 0,4114 \\
\hline BKTO & $-1,127151$ & 1,708330 & $-0,659797$ & 0,5103 \\
\hline BYK & $-2,318058$ & 1,721501 & $-1,346534$ & 0,1800 \\
\hline NO & 6,307099 & 6,228437 & 1,012630 & 0,3127 \\
\hline PD & 0,035077 & 0,170418 & 0,205828 & 0,8372 \\
\hline TOTA & $-2,165826$ & 2,041426 & $-1,060938$ & 0,2903 \\
\hline \multicolumn{5}{|c|}{ Etki Özellikleri } \\
\hline R-squared & 0,627198 & \multicolumn{3}{|c|}{ Mean dependent var 1,069333} \\
\hline Adjusted R-squared & 0,507533 & \multicolumn{2}{|c|}{ S.D. dependent var } & 2,918640 \\
\hline S.E. of regression & 2,048185 & \multicolumn{3}{|c|}{ Akaike info criterion 4,481766} \\
\hline Sum squared resid & 679,5998 & \multicolumn{2}{|c|}{ Schwarz criterion } & 5,312668 \\
\hline Log likelihood & $-428,7899$ & \multicolumn{3}{|c|}{ Hannan-Quinn criter.4,817489 } \\
\hline F-statistic & 5,241286 & \multicolumn{2}{|c|}{ Durbin-Watson stat } & 1,494775 \\
\hline Prob(F-statistic) & 0,000000 & & & \\
\hline
\end{tabular}

Kriz öncesi dönemi gösteren Tablo 4'e bakıldığında modelin genel olarak anlamlı olduğu ve bağımsız değişkenlerden hiçbirinin bağımlı değişken TO ile istatistiksel olarak anlamlı bir ilişkisi olmadığı görülmektedir.

Kriz sonrası dönemi (2009-2016) gösteren Tablo 5 incelendiğinde modelin genel olarak anlamlı olduğunu ve bağımsız değişkenlerden sadece PD ve NO ile TO arasında istatiksel olarak anlamlı bir ilişki olduğu görülmektedir. PD'deki \%1'lik değişim TO'da aynı yönde \%10,15'lik bir değişime neden olurken, NO'daki \%1'lik değişim TO'da aynı yönde \%53,67 gibi yüksek oranda bir değişime neden olmaktadır. Bu durum kriz sonrası dönemde yaşanan likidite sıkıntısının açık bir kanıtı niteliğindedir. 
Tablo 5. Model 3 (Kriz Sonrası) için EGLS Sonuçları

\begin{tabular}{|c|c|c|c|c|}
\hline $\begin{array}{l}\text { Bağımsız Değişken: } \\
\text { Yöntem: Panel EGLS } \\
\text { Dönem: } 2009-201 \\
\text { Zaman Boyutu Göz| } \\
\text { Yatay Kesit Gözlem } \\
\text { Total Panel (dengel }\end{array}$ & $\begin{array}{l}\text { TO } \\
\text { S (Cross-sec } \\
6 \\
\text { lem Sayısı T } \\
\text { Sayısı N: } 43 \\
\text { i) Gözlem S }\end{array}$ & $\begin{array}{l}\text { tion weigh } \\
8 \\
\text { ayısı: } 344\end{array}$ & & \\
\hline Değişken & Katsayı & Std. Hata & t-i̇statistiği & Prob. \\
\hline TOTA & 0,099931 & 0,111468 & 0,896496 & 0,3707 \\
\hline PD & 0,101540 & 0,017889 & 5,676191 & 0,0000 \\
\hline NO & 0,536725 & 0,227949 & 2,354580 & 0,0192 \\
\hline BYK & 0,063346 & 0,044950 & 1,409258 & 0,1598 \\
\hline BKTO & 0,221322 & 0,139334 & 1,588431 & 0,1133 \\
\hline AK & 0,002904 & 0,003113 & 0,932726 & 0,3517 \\
\hline $\mathrm{C}$ & $-0,891940$ & 0,968171 & $-0,921263$ & 0,3577 \\
\hline \multicolumn{5}{|c|}{ Etki Özellikleri } \\
\hline R-squared & 0,642101 & \multicolumn{3}{|c|}{ Mean dependent var1,697496 } \\
\hline Adjusted R-squared & 0,583867 & \multicolumn{3}{|c|}{ S.D. dependent var 1,825640} \\
\hline S.E. of regression & 1,329976 & \multicolumn{2}{|c|}{ Sum squared resid } & 521,8070 \\
\hline F-statistic & 11,02615 & \multirow{2}{*}{\multicolumn{2}{|c|}{ Durbin-Watson stat }} & 1,429114 \\
\hline Prob(F-statistic) & 0,000000 & & & \\
\hline
\end{tabular}

\section{Sonuç}

Temettü konusu, firmaların yatırım ve finansman politikasının ayrılamaz bir parçası olarak gerek yatırımcılar gerekse firmalar açısından oldukça önemlidir. Bugüne kadar konuya ilişkin yapılmış sayısız çalışma mevcuttur. Miller ve Modigliani (1961)'nin mükemmel piyasa koşullarında firmanın temettü politikasının firma değerinden bağımsız olduğunu ileri sürdüğü ilintisizlik teorisinin aksine finans dünyasında, günümüz piyasa koşullarının mükemmel olmaması, yatırımcıların sınırlı rasyoneliteye sahip olması gibi birçok faktör nedeniyle temettü ödemelerinin firmanın piyasa değeri üzerine etkili olduğu sonucu hâkimdir. Bu noktada temettü ödemelerinin piyasa değeri üzerinde olumlu ve olumsuz etkisi olabileceğine dair farklı görüşler ortaya atılmıştır. Bu çalışmada temettü politikasını etkileyen faktörlerin neler olduğu ve temettü politikasına ilişkin geliştirilen teorik yaklaşımların geçerliliklerinin test edilmesi amaçlanmıştır. Bununla beraber çalışmanın temel amaçlarından biri; temettü politikasını etkileyen faktörlerin ve teorik yaklaşımların, finansal kriz gibi belirsizliğin ve riskin yoğunlaştığı dönemlerde ne şekilde değişiklik göstereceğinin incelenmesidir.

Bu amaç doğrultusunda yaşanan en güncel ve küresel kriz olan 2008 finansal krizi temel alınarak BiST 100 Endeksi'nde listelenen 43 firmadan oluşan örneklemin, 2004-2016 yılları arasındaki verileri kullanılarak panel veri analizi gerçekleştirilmiştir. Krizin etkisini görmek amacıyla analiz dönemi kriz öncesi (2004-2008), kriz sonrası (2009-2016) ve tüm dönem (2004-2016) olarak üçe ayrılmıştır. Söz konusu üç dönem için kurulan modelde temettü ödeme oranı bağımlı değişken olarak belirlenmiştir. Firma büyüklüğü, aktif karlılı̆ı, piyasa değeri/defter değeri, birikmiş kar/toplam özkaynak, toplam özkaynak/toplam aktif ve nakit oran değişkenleri modele bağımsız değişken olarak dâhil edilmiştir. Analiz sonuçlarına göre; tüm analiz dönemi içerisinde bağımlı değişken temettü oranını pozitif yönde ve istatistiksek olarak anlamlı bir şekilde etkileyen bağımsız değişkenler; piyasa değeri/defter değeri, aktif kârılığı ve birikmiş kâr/toplam özkaynak oranı olmuştur. Bu sonuçlara göre kârlı ve olgunluk seviyesindeki firmaların daha fazla temettü dağıtma eğiliminde olduğu ve 
sonucun yaşam döngüsü teorisiyle uyumlu olduğu görülmüştür. Kriz öncesi dönem için bağımsız değişkenler ile temettü ödeme oranı arasında anlamlı bir ilişkiye rastlanmamıştır. Kriz sonrası dönemde ise piyasa değeri/defter değeri ve nakit oranı, temettü ödeme oranı ile pozitif ve anlamlı bir ilişkiye sahiptir. Özellikle nakit oranı ile temettü ödeme oranı arasındaki ilişkinin kuvveti, kriz sonrası dönemde likiditenin her zamankinden önemli bir hâle geldiği göstermektedir. Bununla birlikte, BiST 100 firmalarının, kriz dönemlerinde ihtiyatlılık gereği ellerinde bulunan nakdi firma bünyesinde tutmak yerine temettü olarak dağıtması, sinyal teorisinin önermelerinin kriz dönemlerinde dahi geçerli olduğunu göstermektedir.

Temettü politikasını etkileyen faktörlerin finansal kriz dönemlerinde değişiklik gösterip göstermediğinin sınanması ve temettü politikasına ilişkin teorik yaklaşımların geçerliliklerinin, Türkiye gibi gelişmekte olan bir ülke üzerinde, özellikle kriz dönemlerinde sınanması açısından çalışma, diğer çalışmalardan farklııık göstermekte ve literatüre katkı sunmaktadır.

Bu çalışmanın örneklemini oluşturan 43 firma çoğunlukla sanayi sektörü içerisinde yer alan firmalardan oluşmakta fakat spor kulüpleri ve hizmet sektöründe yer alan birkaç firma da örneklem içinde yer almaktadır. Bu çalışmadan sonra yapılacak araştırmalarda temettü ödeme politikalarına dair daha etkin sonuçlar elde etmek için analiz, belirli bir sektör içerisindeki firmalar üzerine gerçekleştirilebilir.

\section{Kaynaklar}

Abor, J., \& Bokpin A. G. (2010). Investment opportunities, corporate finance, and dividend payout policy: Evidence from emerging markets. Studies in Economics and Finance, 27(3), 180-194.

Abreu, J. F., \& Galumhussen, M. A. (2013). Dividend payouts: Evidence from U.S. bank holding companies in the context of the financial crisis. Journal of Corporate Finance, 22, 54- 65.

Adaoğlu, C. (2000). Instability in the dividend policy of the Istanbul Stock Exchange (ISE)

corporations: Evidence from an emerging market. Emerging Markets Review, 1, 252-270.

Aksöyek, I., \& Yalçıner, K. (2011). Çözümlü problemleriyle finansal yönetim (1. Baskı). İstanbul: İstanbul Bilgi Üniversitesi Yayınları.

Al-Kuwari, D. (2009). Determinants of the dividend policy in emerging stock exchanges: the case of GCC countries. Global Economy \& Finance Journal, 2(2), 38-63.

Aygören, H., Çakır, H.M., \& Uyar, U. (2013). Ekonomik krizlerin iMKB'de temettü politikaları üzerine etkisi. E-Journal of New World Sciences Academy, ISSN: 1308-7444.

Baltagi, B.H., \& Li, Q. (1995). Testing $A R(I)$ against $M A(I)$ disturbances in an error component model. Journal of Econometrics, 68, 133-151.

Baltagi, B. H. (2005). Econometric analysis of panel data (3. Baskı). Chichester: John Wiley \& Sons.

Bhattacharya, S. (1979). Imperfect information, dividend policy, and the bird in the hand fallacy. The Bell Journal of Economics, 10(1), 259-270.

Born, B., \& Breitung, J. (2016). Testing for serial correlation in fixed-effects panel data models. Econometric Reviews, 35(7), 1290-1316.

Bozos, K., Nikolopoulos, K., \& Ramgandhi, G. (2011). Dividend signaling under economic adversity: Evidence from the London Stock Exchange. International Review of Financial Analysis, 20, 364-374.

Breusch, T. S., \& Pagan, A. R. (1979). A simple test for heteroscedasticity and random coefficient variation. Econometrica, 47(5), 1287-1294.

Çelik, S. (2013). Kâr payı politikası ve yaşam döngüsü teorisi: IMKB imalat sektöründe ampirik bir uygulama. Anadolu Üniversitesi Sosyal Bilimler Dergisi, 13(2), 115-122.

De Angelo, H., De Angelo, L., \& Stulz, R.M. (2006). Dividend policy and the earned/contributed capital mix: A test of the life-cycle theory. Journal of Financial Economics, 81, 227-254.

Demirel, E. (2014). Temettü dağııım politikasının firma değeri üzerine etkisi ve BiST 30 Endeksinde bir uygulama. Selçuk Üniversitesi Sosyal Bilimler Enstitüsü, Yayımlanmamış Yüksek Lisans Tezi, Konya.

Easterbrook, F. H. (1984). Two agency-cost explanations of dividends. The American Economic Review, 74(4), 650-659. 
Erlat, H. (2015). Panel data: A selective survey. Department of Economics Middle East Technical University, No: 06800.

Fama, E. F., \& French, K. R. (2001). Disappearing dividens: Changing firm characteristics or lower propensity to pay? Journal of Financial Economics, 60(1), 3-43.

FiNNET, (2017). www.finnet.com.tr (Erişim tarihi, 25 Ağustos 2017).

Gelir İdaresi Başkanlığı, (2016). Menkul sermaye iradı elde edenler için gelir vergisi beyanname düzenleme rehberi, Yayın No: 211, Mükellef Hizmetleri Daire Başkanlığı, Ankara.

Gordon, M. J. (1963). Optimal investment and financing policy. The Journal of Finance, 18(2), 264-272.

Gürsoy, C.T. (2007). Finansal yönetim ilkeleri (1. Baskı). İstanbul: Doğuş Üniversitesi Yayınları.

Hsiaso, C. (2005). Why panel data? Institute of Economic Policy Research, IEPR Working Paper 05.33.

Jensen, M.C. (1986). Agency costs of free cash flow, corporate finance, and takeovers. The American Economic Review, 76(2), 323-329.

Kargın, S. (2006). Temettü politikasının temsil maliyetleri üzerindeki etkisi ve kurumsal yönetime katkısı. Celal Bayar Üniversitesi Sosyal Bilimler Enstitüsü, Yayımlanmamış Doktora Tezi, Manisa.

Kirkulak, B., \& Kurt, G. (2010). Are dividends disappearing or shrinking? Evidence from the Istanbul Stock Exchange. Emerging Markets Finance and Trade, 46(2), 38-52.

Kouser, R., Luqman, R., Yaseen, A., \& Azeem, M. (2015.) Dividend payout policy and financial crisis: Evidence from the life cycle theory. Pakistan Journal of Commerce and Social Sciences, 9(2), 583-597.

Lintner, J. (1956). Distribution of incomes of corporations among dividens, retained earnings, and taxes. The American Economic Review, 46(2), 97-113.

Lintner, J. (1962). Dividends, earnings, leverage, stock prices and the supply of capital to corporations. The Review of Economics and Statistics, 44(3), 243-269.

Mehdi, M., Sahut, J. M., \& Teulon, F. (2017). Do corporate governance and ownership structure impact dividend policy in emerging market during financial crisis. Journal of Applied Accounting Research, 18(3), 274-297.

Miller, M. H., \& Modigliani, F. (1961). Dividend policy, growth, and the valuation of shares. The Journal of Business, 34(4), 411-433.

Pekkaya, M. (2006). Kar payı dağıtımının şirket değeri üzerine etkisi: IMKB 30 endeks hisselerine bir analiz. ZKÜ Sosyal Bilimler Dergisi, 2(4), 183-209.

Rozeff, M. S. (1982). Growth, beta and agency costs as determinants of dividend payout ratios. The Journal of Financial Research, 5(3), 249-259.

SPK, (2016). www.spk.gov.tr (Erişim tarihi, 3 Haziran 2016).

Taş̧̧ı, H. (2017). Finansal krizlerin firmaların temettü politikasına etkisi: 2008 krizi temelinde BisT 100 Endeksi'nde listelenen firmalar üzerine bir uygulama. Mersin Üniversitesi Sosyal Bilimler Enstitüsü, Yayımlanmamış Yüksek Lisans Tezi, Mersin.

Tatoğlu, F. Y. (2016). Panel veri ekonometrisi (3. Baskı). İstanbul: Beta Basım.

Van Horne, J. C., \& Jr. Wachowicz, J. M. (2008). Fundamentals of financial management (13th Edition). London: Prentice Hall. 